\title{
Katarzyna Król*
}

Uniwersytet Łódzki

ORCID: 0000-0003-1352-2118

\section{WOLONTARIUSZ NIEPEŁNOSPRAWNY - Z POTRZEBY WŁASNEJ CZY MYŚLENIA O INNYCH}

\begin{abstract}
„Najbardziej niezmiennym i ważnym pytaniem życia jest: Co robisz dla innych?” (Martin Luther King Jr). To właśnie jest istota wolontariatu, która polega na świadomej oraz bezinteresownej pracy na rzecz społeczności, to okazywanie pomocy, ale też lekcja proszenia o nią. Odpowiedź na tak postawione pytanie nie jest łatwa, zwłaszcza dla osoby niepełnosprawnej. Celem artykułu jest próba odpowiedzi na pytanie, czy osoba niepełnosprawna może być również dawcą działań wolontariackich, a nie tylko ich biorcą. Szczególne miejsce w analizie aktywności społecznej, jaką jest między innymi wolontariat, mają kwestie dotyczące osób niepełnosprawnych. Uczestnictwo społeczne, związane z nim mechanizmy integracji lub wykluczenia są zjawiskami o charakterze procesualnym. Prowadzone przeze mnie badania niepełnosprawnych wolontariuszy są próbą odpowiedzi na pytania: jakie czynniki, procedury czy mechanizmy stoją za podjęciem aktywności społecznej lub jej brakiem, czy działalność wolontariacka osób niepełnosprawnych jest pożądaną drogą wyjścia z kręgu osób biernych, wykluczonych. Dla osób z ograniczeniami sprawności, aktywność społeczna mogłaby bowiem stać się alternatywnym źródłem pozyskiwania pomocy, wsparcia, a także pozytywnym „lustrem”, mogącym wpłynąć na podniesienie ich samooceny. Badanie skoncentrowałam na wolontariuszach z niepełnosprawnością ruchową.
\end{abstract}

Słowa kluczowe: niepełnosprawność ruchowa, wolontariusze niepełnosprawni, działania wolontariackie, aktywność społeczna, aktywizacja

\section{WPROWADZENIE}

Ludzie od wieków pomagali sobie wzajemnie w różnym zakresie, formach, kierowani różnorodnymi motywacjami. Mimo że współczesny rozwój technologii daje ludziom wiele możliwości działania, to nadal człowiekowi po prostu potrzebny jest drugi człowiek. Ponad siedem miliardów ludzi codziennie koegzystuje ze sobą, wchodząc w różnorakie relacje. I to człowiek we współpracy z drugim człowiekiem jest w stanie stawić czoła stojącym przed nim wyzwaniom. Jak pokazuje obecna sytuacja na świecie związana z zagrożeniem epidemicznym, tylko wspólne zaangażowanie wielu osób, w tym i wolontariuszy pozwala na skuteczniejszą realizację podejmowanych działań pomocowych.

* Adres do korespondencji: Katarzyna Król, Uniwersytet Łódzki, Instytut Socjologii, Katedra Socjologii Organizacji i Zarządzania, ul. Rewolucji 1905 r. nr 41, 90-214 Łódź, Polska; e-mail: krol_kasia@wp.pl. 
Nie jest łatwo jednoznacznie zdefiniować pojęcia „wolontariat”, ponieważ w literaturze przedmiotu istnieje wiele znaczeń. Słowo wolontariat, pochodzące od łacińskiego volontarius (dobrowolny, chętny), oznacza nieodpłatne, świadome i dobrowolne działanie na rzecz innych osób, społeczności czy organizacji (Słownik języka polskiego PWN 2015). Jest to termin stosunkowo nowy o niewykrystalizowanym jeszcze do końca zakresie znaczeniowym. Został wprowadzony do polskiej literatury na początku lat dziewięćdziesiątych XX wieku wraz z rozwojem różnego rodzaju organizacji pozarządowych, odgrywających coraz większą rolę w kształtowaniu życia społecznego. Do tego czasu cała sfera działalności społecznej realizowanej przez ochotników i działaczy społecznych nazywana była filantropią, dobroczynnością, działalnością charytatywną lub pracą społeczną. W polskiej literaturze przedmiotu wolontariat często określany jest jako „dobrowolna, świadoma, bezpłatna i systematyczna działalność na rzecz innych" (Fabisiak 2002: 5), którą podejmują wolontariusze. Według Ustawy z dnia 24 kwietnia 2003 r. o działalności pożytku publicznego i o wolontariacie, wolontariuszem jest osoba, która ochotniczo i bez wynagrodzenia wykonuje świadczenia odpowiadające świadczeniu pracy na zasadach określonych w ustawie na rzecz między innymi organizacji pozarządowych, organów administracji publicznej i jednostek im podległych lub przez nie nadzorowanych (zgodnie z art. 2 i 42).

Anna Kanios (2010: 50) podkreśla, że wolontariat stanowi ,zróżnicowany ruch społeczny, który można opisać poprzez wskazanie jego istotnych elementów". Wolontariat daje szansę wykorzystania własnych umiejętności i doświadczeń, rozwinięcia zainteresowań, zdobycia doświadczenia w nowych dziedzinach, zawarcia przyjaźni. Zakłada pewną ciągłość i systematyczność w działaniach. Pomoc w ramach wolontariatu może być świadczona w różnoraki sposób i obejmować cały szereg działań. Jest nią nieodpłatna, dobrowolna praca świadczona na rzecz osób spoza własnego gospodarstwa domowego (w tym na rzecz niezamieszkującej wspólnie rodziny, przyjaciół, sąsiadów, ale także na rzecz osób nieznajomych), na rzecz środowiska naturalnego, społeczeństwa lub społeczności lokalnej, podejmowana indywidualnie albo w ramach organizacji lub instytucji (Górecki 1999).

Wolontariat jako aktywność społeczna nabiera we współczesnym świecie coraz większego znaczenia. Według badań opublikowanych w 2017 roku przez Główny Urząd Statystyczny, dotyczących wolontariatu w 2016 roku, w Polsce około 10,8 miliona osób dobrowolnie poświęciło swój wolny czas na wolontariat. Badano osoby świadczące wolontariat w ramach struktur sformalizowanych i niesformalizowanych, biorąc pod uwagę różne wskaźniki, na przykład wiek, płeć, stopień wykształcenia, miejsce zamieszkania, czas przepracowany, jego wartość itp. Omówiono różne grupy społeczne. Niestety nie zostały wyróżnione działania wolontariackie osób niepełnosprawnych, mające, jak sądzę, w analizie aktywności społecznej istotne znaczenie. Osoba niepełnosprawna ruchowo postrzegana jest stereotypowo jako ta, która potrzebuje pomocy wolontariusza. Przekaz wizerunkowy takiej osoby pokazuje na ogół jej bezradność, stygmat choroby, roszczeniowość. A przecież spotykamy osoby niepełnosprawne aktywne zawodowo, uczące się, działające w organizacjach pozarządowych, aktywne społecznie. Generalnie jednak w percepcji społecznej osoba niepełnosprawna postrzegana jest schematycznie jako odbiorca działań pomocowych. Pojawia się więc pytanie, czy może być również dawcą takich działań. We współczesnym społeczeństwie osoby niepełnosprawne 
podejmują coraz częściej aktywne działania, starając się tym samym zmieniać stereotypowe postrzeganie ich dysfunkcji. Często jest to udział w pracach formalnych organizacji pozarządowych, ale niejednokrotnie także podejmowanie aktywności w inicjatywach instytucji nieformalnych. Jak wynika z dotychczasowych badań, aktywność społeczna osób niepełnosprawnych jest niższa w porównaniu z aktywnością osób sprawnych. Jak więc zmotywować osoby niepełnosprawne, by podjęły aktywność nie tylko zawodową, ale przede wszystkim społeczną? Jakie czynniki determinują podjęcie lub zaniechanie ich aktywności? Czy zaangażowanie się w działania wolontariackie i zdobyte tam doświadczenie przyczynia się do większej aktywności w innych obszarach życia? Prowadzone przeze mnie badania niepełnosprawnych wolontariuszy są próbą odpowiedzi na powyższe pytania.

\section{DYLEMAT OSOBY NIEPEŁNOSPRAWNEJ - PASYWNOŚĆ CZY AKTYWNOŚĆ}

Potrzeba działania społecznego jest nierozerwalnie związana z życiem człowieka, jego aktywnością w różnych formach uczestnictwa społecznego. Działania społeczne stanowią jeden z najbardziej elementarnych procesów społecznych. Sam termin „działanie” oznacza aktywność człowieka - jego zachowanie - podejmowane ze względu na potrzebę osiągnięcia pewnego celu. Działanie społeczne staje się tym samym działaniem człowieka ukierunkowanym na innych ludzi. Termin działania społecznego rozwijał socjolog Max Weber, a następnie między innymi Talcott Parsons. Aktywni, świadomi swoich praw i obowiązków obywatele, wchodząc w relacje interpersonalne, tworząc sieci społeczne, angażują się we wspólne działania na rzecz dobra wspólnego.

Zakres funkcjonowania społecznego określany jest przez poziom aktywności społecznej, stosunki społeczne, motywacje, umiejętności społeczne. Współczesna literatura przedmiotu, zajmując się zagadnieniem aktywności społecznej, koncentruje się przede wszystkim na analizie trzeciego sektora. Badacze w większości przyjmują ujęcie sprowadzające pojęcie społeczeństwa obywatelskiego do problematyki organizacji pozarządowych (Misztal 2007). Nieuwzględnienie jednak w obszarze aktywności obywatelskiej nieformalnych, spontanicznych działań jednostek byłoby dużym zaniedbaniem (Marody 2019). Współczesne procesy makrostrukturalne powodują bowiem wzrastającą rolę zachowań pomocowych często o charakterze nieformalnym. Jak zauważa Jolanta Grotowska-Leder (2008: 11), wynika to z niewystarczającego wsparcia społecznego rodziny i państwa. W analizach socjologicznych uczestnictwo społeczne jest analizowane z dwóch perspektyw: segmentacyjnej i całościowej. W perspektywie segmentacyjnej wyodrębnia się różne sfery, w których zachodzą stosunki społeczne, na przykład zatrudnienie, czas wolny, życie rodzinne, i bada się związaną z nimi aktywność jednostki. W perspektywie całościowej nawiązuje się do stylów życia, ogarnia się całość ludzkiej egzystencji, ukazuje się różne powiązania uwarunkowane czynnikami zewnętrznymi i subiektywnymi zabiegami nadawania sensów.

Pojęcia „zaangażowanie obywatelskie”, „aktywność społeczna” czy „aktywność obywatelska" są bardzo różnie definiowane. Niektórzy autorzy podkreślają znaczenie partycypacji 
w formalnych strukturach, takich jak organizacje społeczne ${ }^{1}$, inni rozumieją ją znacznie szerzej jako udział w instytucjach demokratycznych, poziom zaufania do nich, uczestnictwo w nieformalnych strukturach lokalnych (np. grupy sąsiedzkie) ${ }^{2}$. Aktywność społeczna rozumiana jako działanie dobrowolne, bezinteresowne i celowe może wyrażać się w trzech różnych wymiarach. Po pierwsze, może ona dotyczyć aktywności jednostki wobec innych jednostek. Po drugie, aktywności wobec określonych zbiorowości, podmiotów zbiorowych środowisk, wspólnot. I w końcu, po trzecie, aktywności wobec procesów programów, ruchów, sił społecznych, politycznych i gospodarczych (Michalik 1998).

Inną definicję aktywności społecznej proponuje Tönnies (Śpiewak 2018). Zwraca on uwagę na dobrowolność i zbieżność działań jednostek. Ta wspólnota celów może przybierać różne formy organizacyjne. Często jest tylko nieformalną grupą osób działających na rzecz rozwiązania danego problemu społecznego. Na potrzeby niniejszych rozważań przyjęłam, że aktywność społeczna jest pojęciem obejmującym działania na rzecz potrzebujących osób, środowiska oraz organizacji i instytucji, czyli wolontariat.

Jak podkreśla Piotr Gliński, aktywność podejmowana w ramach wolontariatu może być rozumiana jako „wspólna i świadoma artykulacja, realizacja i obrona interesów (potrzeb, aspiracji) jakiejś grupy społecznej przez jej członków. Szczególnie istotny w powyższej definicji jest [...] aspekt świadomości wspólnego działania" (Gliński i Palska 1996: 365). W koncepcjach naukowych dotyczących wymiarów aktywności społecznej Polaków wskazuje się na „enklawowość” tego zjawiska. Ma ona niejako podwójny wymiar - dotyczy określonych, bardziej niż inne aktywnych grup społecznych oraz specyficznych problemów, w których rozwiązywaniu uczestniczą osoby zaangażowane w pracę społeczną (Gliński i Palska 1997).

Szczególne miejsce w analizie aktywności społecznej mają kwestie dotyczące osób niepełnosprawnych. Sytuacja osób niepełnosprawnych staje się w ostatnich latach przedmiotem rosnącego zainteresowania badawczego socjologii stosowanej. Tendencja ta pozostaje w związku z intensywnym rozwojem polityki inkluzyjnej. Zbiorowość osób niepełnosprawnych staje się coraz bardziej widoczna w różnych dziedzinach życia społecznego. W literaturze naukowej dotyczącej osób niepełnosprawnych w głównej mierze podejmowane są zagadnienia związane z aktywizacją zawodową, społeczną, edukacją, warunkami opieki zdrowotnej, barierami. Badania w szczególności skierowane są na aktywność wolontariacką wobec osób niepełnosprawnych, a nie na aktywność ich samych. Dla osób z ograniczeniami sprawności, „sfera aktywności życiowej (aktywności społecznej i obywatelskiej) istotna jest przede wszystkim dla osób, których niepełnosprawność nie przeszkadza w codziennym funkcjonowaniu" (Wiszejko-Wierzbicka 2010: 56). Osoba niepełnosprawna ruchowo, podejmując aktywność społeczną, mierzy się z wieloma problemami, czy to natury fizycznej, czy psychologicznej. $\mathrm{Z}$ jednej strony jej aktywność ograniczają bariery architektoniczne, którym fizycznie nie jest

\footnotetext{
Według Australian Bureau of Statistics: realizowanie działań odzwierciedlających interesy i zaangażowanie w rządzenie (governance) oraz demokrację, takie jak członkostwo w partiach politycznych i związkach zawodowych (stowarzyszeniach zawodowych), pełnienie funkcji w klubach i stowarzyszeniach, kontaktowanie się z parlamentarzystami oraz uczęszczanie na zebrania i konsultacje społeczne.

2 Według T. Healy’ego: na aktywność obywatelską składają się takie elementy, jak: głosowanie w wyborach, udział w grupach obywatelskich i partiach politycznych, postrzeganie sąsiedztwa i usług lokalnych oraz zaufanie do instytucji lokalnych i krajowych.
} 
Wolontariusz niepełnosprawny - z potrzeby własnej czy myślenia o innych

w stanie sprostać. Z drugiej strony napotyka bariery społeczne, psychologiczne, prawne czy materialne. Staje więc przed dylematem: być osobą aktywną, pokonywać różnorakie bariery czy nie narażać się na kłopoty, pozostać bierną, nie podejmować wysiłku dokonania zmiany w swoim życiu.

\section{WOLONTARIAT FORMĄ AKTYWNOŚCI SPOŁECZNEJ}

„Bycie niepełnosprawnym oznacza nieustanną konfrontację z problemami w codziennym funkcjonowaniu w rodzinie, w pracy, w urzędzie, na ulicy. Bycie niepełnosprawnym to częste zmaganie się z życiem w izolacji i na marginesie społeczeństwa. To napotykanie barier" (Ostrowska i Sikorska 1997: 187). Różne dysfunkcje wpływają w mniejszym lub większym stopniu na funkcjonowanie człowieka, na środowisko, na relacje z innymi. Osoba z niepełnosprawnością potrzebuje umiejętności, które pozwolą jej uzyskać lub odzyskać samodzielność oraz poczucie własnej wartości.

W badaniach naukowych niepełnosprawność jako problem społeczny rozpatrywana jest z różnych perspektyw (Barnes i Mercer 2004), często przeciwstawnych. Jedną z nich jest idea „empowerment”, upełnomocnienia osób niepełnosprawnych, która powstała jako konsekwencja społecznego pojmowania niepełnosprawności. Jak zauważa Grażyna Mikołajczyk-Lerman (2013), w ewolucji socjologicznych podejść do niepełnosprawności nastąpiło przejście od modelu pomocowo-dobroczynnego do modelu opartego na prawach człowieka. Zasadniczymi elementami koncepcji opartej na poszanowaniu praw są uprawnienia i odpowiedzialność. Empowerment w tym kontekście oznacza uczestnictwo osób niepełnosprawnych jako aktywnych podmiotów, a odpowiedzialność odnosi się do obowiązku instytucji publicznych $\mathrm{i}$ innych struktur do zapewnienia realizacji tych praw (Mikołajczyk-Lerman 2013: 34). Według Zbigniewa Woźniaka, model oparty na prawach człowieka (the humanrights model), nazywany także często modelem socjopolitycznym, jest wielowątkową kwintesencją wszystkich koncepcji osadzonych w modelu społecznym (2008: 78-79). W koncepcji tej przyjmuje się, że wszyscy ludzie są aktywnymi podmiotami z należnymi im prawami, a osoby z niepełnosprawnością mają prawo do uczestnictwa we wszystkich sferach życia społecznego na równi $\mathrm{z}$ osobami pełnosprawnymi. Ostatnie $\mathrm{z}$ omawianych tu podejść jest jednocześnie koncepcją najbardziej holistyczną i w konceptualizacji niepełnosprawności integruje wątki medyczne, rehabilitacyjne, psychologiczne, społeczne, kulturowe i prawne. Niepełnosprawność w biopschospołecznej koncepcji jest procesem znacznie bardziej złożonym, dynamicznym i zmiennym w czasie, niż to zakładały dwa wcześniej wspomniane modele. W omawianym modelu kluczowy jest zakres, w jakim osoby niepełnosprawne włączane są do uczestnictwa w społeczeństwie. Niepełnosprawność traktowana jest jako dynamiczny proces interakcji między jednostką a środowiskiem. Zwraca się uwagę na fakt, że każdy człowiek jest w jakiś sposób niepełnosprawny w różnych okresach swojego życia, a społeczeństwo jest bardziej dostosowane tylko do potrzeb niektórych. Tak więc - w danym obszarze kulturowym - niepełnosprawność wymaga wzajemności i integracji. Takie przyjęcie perspektywy społecznej promuje podejście aktywizujące, podkreślające znaczenie partycypacji, wsparcia usamodzielnienia (Rymsza 2013: 78-98). 
Niepełnosprawność na przełomie XX i XXI wieku coraz częściej była przedmiotem publicznej debaty i nabrała wymiaru politycznego. Aktywność środowisk osób niepełnosprawnych spowodowała ukształtowanie się i rozwinięcie społecznej konstrukcji niepełnosprawności (Barnes 1991). To działania na rzecz osób niepełnosprawnych podejmowane przez osoby aktywne w dużej mierze przyczyniły się do nowego sposobu spojrzenia na funkcjonowanie, położenie społeczno-ekonomiczne środowiska. W badaniach naukowych wiele uwagi poświęca się problemom wsparcia i aktywizacji osób niepełnosprawnych (Gąciarz 2014; Rymsza 2016). W literaturze przedmiotu podnoszone są często zagadnienia dotyczące inkluzji, integracji czy dyskryminacji osób niepełnosprawnych (Giermanowska et al. 2015). Badania naukowe dotyczące polityki społecznej wobec osób niepełnosprawnych po 1989 roku wskazują, że już w pierwszych latach transformacji państwo tworzyło przestrzeń dla aktywności społecznej i obywatelskiej (Prawo o stowarzyszeniach, Dz.U. z 1989 r., nr 20), a środowiska osób niepełnosprawnych stały się jednymi z pierwszych beneficjentów działań pomocowych i samopomocowych w ramach organizacji pozarządowych.

Antonina Ostrowska podkreśla, że ,zgodnie z założeniami bio-psycho-społecznego modelu niepełnosprawności postuluje się, aby w działaniu praktycznym zamiast wspomagania osoby niepełnosprawnej w jej przystosowaniu się do otoczenia, mieć na uwadze raczej kwestię gotowości społeczeństwa na dostosowanie posiadanych wzorów i oczekiwań do możliwości osób niepełnosprawnych" (Ostrowska i Sikorska 1997). To nie tylko osoba niepełnosprawna musi pokonywać różnorakie bariery, ale również społeczeństwo winno stwarzać takie warunki, by osoba nie w pełni sprawna mogła żyć pełnią życia. W życiu społecznym osób niepełnosprawnych najważniejsza jest normalizacja, czyli zachowanie i rozwijanie takich norm i zachowań, które są możliwie najbardziej zgodne z normami kulturowymi środowiska.

Aktywność osób niepełnosprawnych zmieniła dotychczasowy model polityki społecznej również w Polsce, w którym niepełnosprawni byli tylko jej przedmiotem, będąc jednocześnie uzależnionymi od ludzi pełnosprawnych. Niepełnosprawni zaczęli wpływać na decyzje dotyczące polityki społecznej, stając się jednocześnie jej współtwórcami. Często bowiem osoby niepełnosprawne doświadczają wykluczenia w relacjach społecznych, są odrzucane, ignorowane, wyśmiewane czy po prostu świadomie niezauważane przez osoby w pełni sprawne. Takie zachowania osób pełnosprawnych powodują deformację interakcji społecznych. Stygmatyzacja społeczna to proces napiętnowania osoby lub grupy ze względu na jakiś, deprecjonowany przez otoczenie, atrybut lub cechę (Goffman 1963/2005). Piętno jest rodzajem procesu społecznego, relacji wydarzającej się między piętnującym i napiętnowanym, prowadzącej często do obniżenia poczucia własnej wartości osoby niepełnosprawnej. Jak słusznie podkreśla Hanna Żuraw, „uczestnictwo osób niepełnosprawnych w głównym nurcie życia zbiorowego ma odznaczać się powszechnością, wszechstronnością, znormalizowaniem i równością" (Żuraw 2007: 9). Wiele osób dostrzegło brak efektywnych działań rządu skierowanych na rozwiązywanie problemów osób niepełnosprawnych. W związku z tym ludzie bezpośrednio zainteresowani problemami niepełnosprawności rozpoczęli tworzenie organizacji pozarządowych (stowarzyszeń, towarzystw, fundacji, grup samopomocowych). Zazwyczaj osobami zaangażowanymi w działalność tego typu organizacji są właśnie osoby niepełnosprawne, a także osoby z ich bliskiego otoczenia. Osoby niepełnosprawne podejmują działania społeczne w różnych formach, najczęściej są to działania oparte na wolontariacie. 
Wychodząc od fundamentalnego założenia, że świadomi obywatele są podstawą obywatelskiego społeczeństwa, działania woluntarystyczne są jednymi z podstawowych form, w których przejawia się uczestnictwo społeczne obywateli. W strukturach formalnych i nieformalnych działających na rzecz osób niepełnosprawnych funkcjonują osoby sprawne i niepełnosprawne, aktywne i będące tylko odbiorcami podejmowanych w ramach zadań statutowych przedsięwzięć. Ważne w funkcjonowaniu takich struktur są relacje między członkami, ich aktywność, zwłaszcza zorientowana na zmianę otaczającej nas rzeczywistości, współodpowiedzialność za dobro wspólne. Sytuacja nie jest korzystna, ponieważ większość inicjatyw podejmowanych na rzecz niepełnosprawnych jest inicjowana właśnie przez stowarzyszenia działające w tym temacie (Sasinowski 2012).

\section{Z POTRZEBY WŁASNEJ CZY MYŚLENIA O INNYCH - INSPIRACJE TEORETYCZNE}

Człowiek uczy się świata przez doświadczanie go. Każda z form społecznej interakcji opiera się na swoistego rodzaju konstruktach, które odnoszą się do większego rozumienia świata i odmiennych w związku z tym wzorów działań. Nawet najprostsza reakcja w codziennym życiu wymaga od jednostki znajomości serii potocznych konstruktów, również w odniesieniu do innych członków społeczeństwa. Jednostka, wykorzystując, w rozumieniu otaczającego świata, a nade wszystko w działaniu, system typifikacji „ujmuje wszelkie konteksty, znaczenia, zachowania [...] nawet samego siebie ujmuje w schematycznych kategoriach" (Dziewulski 1984: 143).

Osoba niepełnosprawna funkcjonuje w wielu grupach i każda $\mathrm{z}$ nich jest dla niej grupą odniesienia z jej wartościami, wzorami. Adaptując się do otoczenia, do wymagań danej zbiorowości, podejmuje interakcje, określane jako symboliczne. W swojej pracy badając doświadczenia osób niepełnosprawnych w działaniach wolontariackich, odnosiłam się do symbolicznego interakcjonizmu. Jak podkreśla Blumer (2007), proces interpretacji jest najistotniejszym elementem w działaniu człowieka i w życiu grup ludzkich. Wchodzenie w role innych, nawet w zorganizowanych układach, włączanie się w system kulturowych symboli i wykorzystywanie ich jako punktów odniesienia do dokonania własnej samooceny i właściwego pokierowania swoim zachowaniem, zapewnia jednostce stabilne miejsce w strukturze społecznej (Turner 1998: 93). Umiejętność przyjmowania roli empatycznego uczestnika interakcji, jak sądzę, jest niezwykle ważna w działaniu wolontariackim, zwłaszcza osoby niepełnosprawnej, która nie tylko oczekuje, ale sama daje wsparcie.

Podjęcie działania mającego na celu aktywność wolontariacką ma swoje motywacyjne podłoże. Z wielu definicji motywacji na potrzeby mojej pracy badawczej wybrałam tę sformułowaną przez J.A.F. Stonera, R.E. Freemana oraz D.R. Gilberta Jr. (Sekuła 2008: 11): „Motywacja to psychologiczny stan przyczyniający się do stopnia, w jakim człowiek się w coś angażuje. Obejmuje czynniki, które powodują, wytyczają i podtrzymują zachowania ludzkie zmierzające w określonym kierunku". Inspiracją do analizy wypowiedzi uzyskanych od wolontariuszy niepełnosprawnych ruchowo była teoria potrzeb A. Maslowa. Potrzeby ułożone są sekwencyjnie, hierarchicznie. Człowiek stara się zaspokoić najpierw potrzeby 
podstawowe, fizjologiczne, które uznawane są zwykle za punkt wyjścia teorii motywacji. Maslow stwierdził, że w przypadku zaspokojenia potrzeby niższego rzędu przestaje być ona źródłem motywacji. Gdy zostaje zaspokojona, pojawia się nowy zestaw potrzeb: potrzeby bezpieczeństwa, potrzeby społeczne (przynależności, miłości), potrzeba szacunku, potrzeba samorealizacji (Maslow 1990). Maslow stwierdził ponadto, że „poziomy hierarchii są ze sobą powiązane, a nie zupełnie rozdzielone". W hierarchii potrzeb szczególnie zainspirował mnie poziom interpersonalny, związany z poczuciem przynależności i akceptacji wśród różnych grup społecznych. Ta potrzeba wpływa bowiem na umiejętność tworzenia i utrzymywania relacji międzyludzkich. Następna z sekwencji potrzeb, to potrzeba szacunku. Ludzie często angażują się w pewne działania, aby zyskać uznanie, akceptację. Te działalności dają człowiekowi poczucie własnej wartości, tak ważne szczególnie dla osoby niepełnosprawnej.

Jak zauważa J. Penc, motywacja stanowi proces wyboru, jakiego dokonują ludzie między różnymi zachowaniami i formami aktywności, aby urzeczywistnić cele będące wynikiem cenionych przez nich wartości (Penc 2000: 8).

Działanie człowieka może być motywowane zewnętrznie lub wewnętrznie, jednak taki prosty podział nie oddaje całej złożoności tego procesu. Zachowanie człowieka motywowane zewnętrznie i wewnętrznie powinno uwzględniać też wrodzone potrzeby autonomii, kompetencji i związku z innymi. W teorii znanej w polskiej literaturze jako teoria samookreślenia lub teoria samodeterminacji (self-determination theory), stworzonej przez Edwarda Deci i Richarda Ryana (Deci 1975; Deci i Ryan 1985, 2008; Deci et al. 1991), podział motywacji stanowi kontinuum od stanu amotywacji, poprzez motywację zewnętrzną, sterowalną, do motywacji wewnętrznej, autonomicznej (Ryan et al. 1991). Teoria samookreślenia podkreśla rolę społecznego kontekstu, który może sprzyjać lub osłabiać motywację wewnętrzną. Zdaniem autorów proces internalizacji oraz procesy motywacyjne funkcjonują optymalnie, gdy potrzeba autonomii osoby niepełnosprawnej jest zaspokajana przez otoczenie (Deci et al. 1991).

W literaturze obszernie zanalizowano motywacje do pracy pracowników, natomiast niewiele publikacji poświęcono wolontariatowi, tej pracy non-profit, której wartość osiąga bardzo znaczne rozmiary. W świetle teorii motywacji wolontariat, zaspokajając potrzeby społeczne, promuje aktywny udział w życiu społecznym. Ponadto nabiera coraz większego znaczenia we współczesnym świecie jako jedna z ważnych form aktywności społecznej.

Bazując na teorii samookreślenia w trakcie wywiadów, starałam się zdiagnozować motywacje do podjęcia działań wolontariackich przez osoby niepełnosprawne ruchowo, czy zgodnie z podziałem dokonanym przez Ryana (Ryan et al. 1991) były to między innymi motywacje zewnętrzne - sterowalne, czy motywacje wewnętrzne - autonomiczne. Motywacja zewnętrzna to motywacja generalnie zorientowana na korzyści materialne. Rozumiana jest też jako to, co się robi dla ludzi lub na rzecz ludzi, aby ich motywować (Ardeńska 2014). Motywacja wewnętrzna charakteryzuje się podejmowaniem zachowania dla przyjemności, satysfakcji wynikającej z samej aktywności. Osoba, która jest zmotywowana wewnętrznie, robi coś z wewnętrznej potrzeby, a radość daje jej sam fakt wykonania określonej czynności lub skutek inny niż osiągnięcie korzyści materialnych (Ardeńska 2014). Motywacja wewnętrzna również nie jest jednorodna i obejmuje motywację wewnętrzną ukierunkowaną na wiedzę, motywację wewnętrzną w kierunku osiągnięć oraz motywację wewnętrzną w stronę stymulacji doznań. Ludzie motywowani wewnętrznie podejmują aktywność ze względu na 
Wolontariusz niepełnosprawny - z potrzeby własnej czy myślenia o innych

zainteresowanie nią samą, wykonują ją bez nacisku, z pełnym poczuciem własnej woli, a bez konieczności uzyskania nagród materialnych czy stawiania im ograniczeń.

\section{METODOLOGIA BADAŃ}

Przedstawione przeze mnie w niniejszym artykule wyniki badań są fragmentem szerszej analizy, której przedmiotem są doświadczenia osób niepełnosprawnych w ramach podejmowanych przez nie działań wolontariackich. Ze względu na specyfikę podjętej problematyki i przyjęte teoretyczne ramy pracy $w$ ramach procedury badawczej zastosowałam metody jakościowe oparte na paradygmacie interpretatywnym. Podejmując badania jakościowe, wybrałam strategię badawczą, jaką jest etnografia socjologiczna, która opiera się na badaniach terenowych. Interesował mnie przede wszystkim bezpośredni kontakt z ludźmi, stanowiący pole badań etnograficznych. Zastosowałam metodę etnograficzną, ponieważ etnografia pozwala poznać dynamiczne zjawiska. Dzięki niej otrzymuje się cenne i trudno dostępne przy zastosowaniu innych metod dane, które pozwalają wyjaśnić obserwowane procesy.

W badaniach zastosowałam technikę wywiadu swobodnego ze standaryzowaną listą poszukiwanych informacji. Ponadto w badaniach wykorzystałam analizę dokumentów. Wspomagałam się dokumentami zastanymi, takimi jak wywiady prasowe, pamiętniki itp.

Narzędziem, którym posłużyłam się w badaniu, była lista dyspozycji, według której przeprowadzałam wywiady. Wśród dyspozycji do wywiadu, z których korzystałam, znalazły się między innymi pytania: Kiedy pierwszy raz przyszła na myśl Panu/Pani chęć podjęcia działań wolontariackich i dlaczego? Skąd Pan/Pani dowiedział się o wolontariacie, czy miał wcześniej styczność z wolontariuszami? Co Pana/Panią zmotywowało do podjęcia takiej działalności? Jaki wpływ ma wolontariat na inne aspekty życia? Jakie cechy rozwinęła w Panu/Pani ta działalność? Czy dzięki wolontariatowi Pan/Pani czegoś nauczył się, coś zdobył, coś się zmieniło? Proszę opowiedzieć o swoich relacjach z ludźmi na tym wolontariacie? Jak zmieniło się postrzeganie niepełnosprawności przez Pana/Panią czy inne osoby dzięki wolontariatowi?

Celem poznawczym pracy jest charakterystyka procesu uczestnictwa społecznego, jego obszaru, form i uwarunkowań w ramach podejmowanych przez osoby niepełnosprawne działań wolontariackich. Uczestnictwo społeczne oraz związane z nim mechanizmy integracji lub wykluczenia są zjawiskami o charakterze procesualnym. Możliwe jest więc zbadanie, jakie czynniki, procedury czy mechanizmy stoją za podjęciem aktywności społecznej lub jej brakiem. Celem praktycznym mojej pracy jest pokazanie możliwości działalności wolontariackiej osób niepełnosprawnych jako formy ich aktywizacji społecznej i przeciwdziałania wykluczeniu społecznemu.

Główny problem badawczy, jaki rozważyłam w swoich badaniach, brzmi: jakie czynniki determinują podjęcie lub zaniechanie aktywności wolontariackiej osób niepełnosprawnych oraz jak wolontariat tej kategorii osób wpływa na ich uczestnictwo społeczne? Natomiast w niniejszym artykule skupiłam się przede wszystkim na analizie motywacji osób niepełnosprawnych w podejmowaniu działań wolontariackich i skutkach tej aktywności w życiu respondentów.

Próbę badawczą stanowiły pełnoletnie osoby niepełnosprawne ruchowo, mieszkające w różnych regionach Polski. Czas badań obejmował lata 2018-2019. Badania skoncentrowałam 
na wolontariuszach z niepełnosprawnością ruchową. Docierałam do nich metodą kuli śnieżnej, przez portale społecznościowe, znajomych, osoby polecające. Przypadki starałam się dobrać tak, aby zapewnić maksymalną zmienność w próbie. Działania wolontariackie podejmowane przez osoby niepełnosprawne są wielorakie, dlatego tak ważne było, aby zbadać ich różnorodność i zmienność. W badanej grupie byli wolontariusze czynni, a także osoby, które zaprzestały aktywności wolontariackiej z różnorodnych przyczyn (praca, zdrowie, sytuacja rodzinna itp.). Grupa badawcza respondentów liczyła czterdzieści dwie osoby pełnoletnie, w tym dwadzieścia siedem kobiet i piętnastu mężczyzn. W badanej populacji wolontariuszy znalazły się osoby w przedziale wiekowym 19-56 lat. Z respondentami przeprowadziłam wywiady swobodne, wykorzystując komunikatory internetowe lub spotykając się osobiście. Nie było możliwe przeprowadzenie obserwacji uczestniczącej w miejscu działań wolontariackich badanych osób niepełnosprawnych. Przyczyny były bardzo różne: duża odległość od miejsca zamieszkania respondentów, zaprzestanie przez niektóre osoby aktywności wolontriackiej. Barierą była też moja niepełnosprawność i trudności z dotarciem do miejsc, gdzie respondenci prowadzili swoje działania.

\section{MOTYWACJE OSÓB NIEPEŁNOSPRAWNYCH DO PODJĘCIA AKTYWNOŚCI WOLONTARIACKIEJ - BADANIA WŁASNE}

W przeprowadzonych przeze mnie badaniach jedno z pytań dotyczy powodów, dla których respondenci zdecydowali się na podjęcie działań wolontariackich. Czy wynika to z potrzeby własnej, czy myślenia o innych? Jakie czynniki determinują podjęcie tego rodzaju aktywności?

AS: Wolontariat to dla mnie chęć niesienia pomocy drugiemu człowiekowi, takiej bezinteresownej pomocy. To dawanie coś od siebie, dawanie części siebie, jak się coś robi.

Respondenci w badaniach podkreślają, że ważnym elementem działań wolontarystycznych jest zaspokojenie potrzeby bycia użytecznym. Wolontariat staje się formą wykorzystania potencjału i chęci działania na rzecz innych. Konstatują, że wolontariat nie musi przynosić gratyfikacji materialnych. Dla moich rozmówców taką gratyfikacją jest dobre samopoczucie, które wypływa ze świadomości, że komuś coś dali, że zmienili pozycję z osób jedynie przyjmujących pomoc i przeszli na drugą stronę - stali się tymi, którzy tę pomoc dają.

S: Ale z powodów egoistycznych, takiego egoizmu dobrze rozumianego. Zaczynasz być wolontariuszem dlatego, żeby się dobrze poczuć. To jest potwierdzone, to jest efekt moich rozmów z moimi znajomymi, którzy byli wolontariuszami. Oni wszyscy twierdzą w prywatnych rozmowach, że chodziło o to, żeby oni się dobrze poczuli, że coś komuś chcieli dać i to jest motor główny.

Ponadto rozmówcy kładą akcent na powiązanie rozwoju osobistego z aktywnością społeczną. Zwracają uwagę na to, że wolontariat daje możliwość nie tylko pomagania innym, ale też realizacji własnych celów, takich jak chęć sprawdzenia siebie w różnych sytuacjach i środowiskach. 
Wolontariusz niepełnosprawny - z potrzeby własnej czy myślenia o innych

M: To było dla mnie ważne, że jak przy okazji realizowałam siebie, mogłam się sprawdzić, a jednocześnie dać coś komuś, więc była taka ogólna korzyść.

Często okazuje się, że taką motywacją jest zauważalna korzyść w postaci realizacji siebie rozumianej jako poczucie przydatności, realizacja marzeń.

AN: Czas w tej fundacji jest nie na etacie. To jest takie moje dziecko, gdzie chcę zrealizować swoje ideały. To rzeczy, o których myślałem już od kilkunastu lat, od nastolatka, to, co już czułem kiedyś i teraz chciałbym zrealizować.

Dla osób niepełnosprawnych praca wolontariacka staje się często po pewnym czasie jednym z najważniejszych elementów ich życia. Zaczynają się utożsamiać z tym działaniem, mocno angażować. Uczestnicy badania podkreślają, że to nie zewnętrzne czynniki mają wpływ na podejmowanie i kontynuowanie pracy wolontariackiej, a ich głęboka, wewnętrzna potrzeba. Praca wolontariacka staje się odskocznią od codziennych problemów, pewnego rodzaju panaceum na negatywne myśli.

AN: Mimo wszystko to rajcuje, daje kopniaka, motywację. Przede wszystkim są dwie rzeczy. Jedna rzecz [to] przede wszystkim jest to, że robisz to, co Ci sprawia niesamowitą przyjemność. Druga rzecz to robisz coś po coś, by nie wpaść w bardzo negatywne myślenie. Nie utonąć w swoich myślach. Negatywnych emocjach. To jest cała prawda, a o tym to ty też wiesz.

AD: Miałam taką jakąś wewnętrzną siłę, która pchała mnie jakby do przodu i zawsze chciałam tam wracać.

Badane osoby niepełnosprawne chcą być zauważane, mają potrzebę realizowania siebie, pokazania swojej dobrej natury, okazania swojej wdzięczności. To taka forma oddania światu dobra, które kiedyś w życiu otrzymali. Ważną gratyfikacją jest dla nich wdzięczność tych, którym się pomaga.

D: Takie uważanie, stwierdzenie, że gdy coś kiedyś się dostało się dobrego, trzeba to przekazać, dać innym, ewentualnie, jeżeli się swoją postawą życiową osiągnęło jakieś pozytywy czy negatywy, to też należy przekazać innym. Po to, żeby inne osoby miały ewentualnie możliwość zmodyfikować swoją ścieżkę wyboru.

AN: To nie jest tak, że jak robisz, dajesz dobro, to zawsze to dobro do ciebie wróci. Czasami nie. Jak wraca to daje tak niesamowite szczęście, satysfakcję i tak dalej.

Motywacje osób niepełnosprawnych ruchowo podejmujących działania w zakresie wolontariatu są bardzo różnorodne. Jak podkreślają rozmówcy, żadne z nich nie oczekiwało gratyfikacji materialnej. Uznają, że wolontariat sam w sobie, wychodząc wprost z definicji, jest działaniem bezinteresownym. Dopiero w dalszej perspektywie, poniekąd jako wartość dodaną umieszczają takie czynniki, jak: wykorzystanie nabytych umiejętności w przyszłej pracy, docenienie ich potencjału intelektualnego. Formą nagrody jest uznanie ich pracy za potrzebną. Pochwała, bycie zauważonym są dla nich ważną formą niematerialnej gratyfikacji za wykonaną pracę. Podejmując się działań wolontariackich, mają także na celu zmianę własnej sytuacji życiowej. 
AD: Tu miałam za to okazję się wykazać, nawet jeżeli były jakieś potknięcia, to zawsze miałam możliwość liczyć na kogoś, kto mi pomoże. Przede wszystkim zawsze mnie doceniano, zawsze mnie chwalono, co mi było bardzo, bardzo potrzebne. Po prostu w życiu właśnie potrzebowałam takiej formy jakby gratyfikacji.

Zgodnie z teorią potrzeb A. Maslowa człowiek w swoim działaniu dąży do zaspokojenia zespołu potrzeb, w tym potrzeby szacunku. „Zaspokojenie potrzeby szacunku do siebie prowadzi do poczucia pewności siebie, wartości, siły, zdolności i bycia na wysokości zadania, do poczucia, że jest się pożytecznym i potrzebnym w świecie. Ale udaremnienie zaspokojenia tych potrzeb wywołuje poczucie niższości, słabości i bezradności” (Maslow 1990: 85). Osoba niepełnosprawna ruchowo funkcjonuje z poczuciem piętna, poczuciem, że jest kimś gorszym, niedocenianym. Rozmówcy wielokrotnie podkreślają, że chcą być traktowani poważnie, z należytym szacunkiem. Lekceważenie, doznanie poczucia wykorzystania przez innych działa na nich demotywująco.

AN: Prosiło mnie parę takich lokalnych gazet o współpracę i w mniejszym lub większym stopniu współpracowałem z nimi. Zależało to od nastawienia przełożonych. Bo jeśli była motywacja, zachęcanie, ale i poważne traktowanie, to jak najbardziej chciałem współpracować. A jeśli wiedziałem, że ktoś mnie wciągnął tylko po to, żeby ktoś tylko się wybił, bo jest niepełnosprawny w ekipie, a ty, jako niepełnosprawny masz wszystko robić, który tak naprawdę nie ma za to nic, nawet słowa dziękuję, to bez sensu.

Maslow wyróżnia również potrzeby dodatkowe, takie jak potrzeba zdobywania wiedzy czy potrzeby estetyczne. Rozmówcy w swoich wypowiedziach akcentują często motywację związaną ze zdobyciem nowych umiejętności. Jest to być może związane ze znaczeniem doświadczenia nabytego podczas wolontariatu i późniejszym wykorzystaniem w pracy lub w CV.

AD: Właśnie wolontariat wybrałam jako swoją drogę, bo żeby móc pracować, to ja najpierw chciałam się czegoś bardzo dobrze nauczyć i w zasadzie to tam się wszystkiego nauczyłam.

Respondenci wskazują również na potrzebę nawiązania kontaktów społecznych. Niepełnosprawność ruchowa ogranicza fizycznie aktywność towarzyską. Kontakty interpersonalne, jak podkreślają osoby badane, w głównej mierze sprowadzają się do rozmów na forach internetowych. Dla respondentów bardzo ważna jest możliwość nawiązania bezpośrednich relacji z innymi osobami.

I: No, bo to jest właśnie taki powód, żeby mieć do kogo usta otworzyć [...]. Są osoby także, które nie chcą siedzieć same, wręcz chcą wyjść do ludzi i wychodzą do ludzi w taki sposób, że zajmują się wolontariatem.

Osoby badane wyróżniają jako motywację do podjęcia działań lub ich zaprzestania swoją niepełnosprawność i związane $\mathrm{z}$ tym różne problemy zdrowotne.

I: Szczerze mówiąc, to moja niepełnosprawność. [...] Jak jestem zajęta, jak działam, jak coś robię, to o tym nie myślę. Bo jestem zajęta. Ten ból jest tam gdzieś z tyłu głowy, i po prostu jest. [...] Myślę, że osoby niepełnosprawne mają takie same powody jak ja na przykład. Żeby nie myśleć o bólu, ja działam, zajmuję się różnymi sprawami. 
Są również przykłady bodźców pozytywnych, gdzie rozmówcy wskazują na inne aktywne osoby niepełnosprawne, które stają się dla nich wzorem możliwości działania i funkcjonowania niezależnego. Uwidocznienie przykładów uczestnictwa społecznego innych osób niepełnosprawnych ruchowo, bezpośredni kontakt, na co zwracają szczególną uwagę badani, daje impuls do podjęcia działań. Z drugiej strony respondenci wskazują również, że nie tylko przykład aktywnych osób niepełnosprawnych motywuje ich do bycia wolontariuszem. Praca wolontariacka osób sprawnych daje asumpt do przemyśleń, inspiracji. W konsekwencji osoby niepełnosprawne ruchowo dostrzegają w sobie potencjał do działania.

AS: Ja widziałam, że ci ludzie, co tam przychodzą do nas, poświęcają swój czas, swoją chęć do działania i to mnie tam zaraziło. Chciałam to robić i potem ja stanęłam w roli takiego wolontariusza.

Początki działań wolontariackich są często stymulowane informacjami uzyskanymi od znajomych, uczestnictwem w projektach prowadzonych przez organizacje III sektora na rzecz osób niepełnosprawnych. Udział w projekcie jest przesłanką do podjęcia samodzielnych działań wolontariackich na rzecz innych.

AD: Do fundacji trafiłam przez przypadek, ponieważ koleżanka ze studiów opowiedziała mi o fundacji. [...] Zgłosiłam się tam do projektu. Bardzo mi się podobało. Później po zakończeniu tego projektu i mojego uczestnictwa w tym projekcie zapytałam się, czy mogłabym zostać w tej fundacji wolontariuszką. I tak się moja droga zaczęła.

Podobną drogą do aktywności wolontariackiej jest uczestnictwo w świetlicy środowiskowej, również jako podopieczna. Badana jednak kładzie nacisk na jakby samoistne stawanie się wolontariuszem. W trakcie swoich pobytów w świetlicy, sama korzystając z pomocy innych wolontariuszy, pomaga młodszym dzieciom $\mathrm{w}$ nauce, bawi się z nimi, opiekuje się. Podobnie robi to młodzież, rówieśnicy narratorki, będący podopiecznymi tych działań środowiskowych. W miarę dorastania przejmują funkcje starszych wolontariuszy, stając się sami aktywnymi społecznikami.

W wywiadach rozmówcy podkreślają też aspekty finansowe, ale w odroczonej przyszłości. Działając wolontariacko, oczekują w przyszłości, że będą pracować, uzyskując korzyści materialne, a jednocześnie będzie to zajęcie sprawiające im radość i satysfakcję.

AS: Z pomaganiem zaczęłam od wolontariatu. I to mi pokazało, że w momencie, kiedy nie miałam żadnych korzyści materialnych, robiłam to wolontaryjnie, wiadomo, no to już mi to dawało wtedy taką chęć, taką radość, że mogę to robić. To, jeżeli widziałam, że w dorosłym życiu dojdzie mi jeszcze wynagrodzenie za [...] pracę z drugim człowiekiem, właśnie, bo ja studiowałam [...] pedagogikę, no to już wiedziałam, że to będzie super, że to cieszy i zadowala, mam radochę z robienia tego, to jeszcze będę się mogła z tego utrzymać i z tego spokojnie żyć.

Niekiedy motywacje podjęcia działań wolontariackich bywają bardzo prozaiczne. Związane są z zainteresowaniem się ciekawą inicjatywą lub filmem inspirującym do jej podjęcia. Wstąpienie w szeregi harcerzy jednego z respondentów było spowodowane uczuciem nudy, chęcią odmiany codziennej monotonii, co jak wynika z późniejszej narracji, zaowocowało aktywnością wolontariacką w działaniach harcerzy Nieprzetartego Szlaku. 
D: Harcerstwo to było z nudów. [...] A ponieważ mi się w tym sanatorium nudziło generalnie, no to stwierdziłem, że OK, że ja do munduru jak najbardziej. No i wylądowałem w Nieprzetartym Szlaku.

Respondenci prezentują też bardziej pragmatyczne motywy swojego działania:

I: Nie bardzo miałam czas, ale po prostu nie było kogo, tak, że się zgłosiłam.

Jak wynika z wybranych przykładów, osoby niepełnosprawne, podejmując decyzje o zaangażowaniu się w działania wolontariackie, kierują się różnymi motywami. Najwięcej osób podjęło pracę wolontariusza z zaspokojenia potrzeby bycia użytecznym. Podejmują działania wolontariackie, bo nie widzą szans na zdobycie satysfakcjonującej pracy, a chcą być aktywni. Osoba niepełnosprawna ruchowo funkcjonuje z poczuciem piętna, ma wrażenie, że jest kimś gorszym, niedocenianym. Rozmówcy wypunktowują, że chcą być traktowani poważnie, z należytym szacunkiem. Lekceważenie, doznanie poczucia wykorzystania przez innych działa na nich demotywująco. W dalszej kolejności występuje potrzeba pomagania innym ze względu na odczuwaną $\mathrm{z}$ tego powodu satysfakcję i wiarę w powracające dobro. Kolejna przesłanka związana jest z nabyciem nowych umiejętności, co w perspektywie czasowej może zaowocować podjęciem pracy. W wywiadach rozmówcy podkreślają też aspekty finansowe, ale w odroczonej przyszłości. Działając wolontariacko, oczekują w przyszłości, że będą pracować, uzyskując korzyści materialne, a jednocześnie będzie to zajęcie sprawiające im radość i satysfakcję. Badani często jako jeden z impulsów do podjęcia działań wolontariackich wymieniają możliwość poznania nowych ludzi, nawiązania znajomości. Kolejna grupa czynników dotyczy zwiększenia poczucia własnej wartości i samorealizacji przez pomaganie innym. Rozmówcy wskazują również, że nie tylko przykład aktywnych osób niepełnosprawnych zmotywował ich do bycia wolontariuszem. Praca wolontariacka ludzi sprawnych dała asumpt do przemyśleń, inspiracji. W konsekwencji osoby niepełnosprawne ruchowo dostrzegły w sobie potencjał do działania. Początki działań wolontariackich są często stymulowane informacjami uzyskanymi od znajomych, uczestnictwem w projektach prowadzonych przez organizacje III sektora na rzecz osób niepełnosprawnych.

\section{WOLONTARIAT KATAPULTĄ DO ZMIAN W ŻYCIU - PODSUMOWANIE}

Jak wykazały przeprowadzone badania, podjęcie działań wolontariackich wpłynęło w znaczący sposób na osoby niepełnosprawne, stanowiło punkt przełomowy. Jeden z respondentów interesująco opisał swoje doświadczenia wolontariackie:

Wózek to nie jest synonim tego, że ktoś ma coś z głową, tylko że po prostu nie może chodzić. Trochę mnie to nauczyło tego, że by funkcjonować ze sprawnymi, to trzeba z siebie bardzo dużo dać. Nie można oczekiwać, że oni dużo zrozumieją, bo oni nie mają prawa niczego zrozumieć. Po prostu oni inaczej funkcjonują i trzeba po prostu, jak krowie na rowie, pewne rzeczy tłumaczyć, które w danym momencie dla mnie były oczywiste. Jeżeli się człowiek nie może dostosować, to musi wyjaśnić. 
Generalnie respondenci, bez względu na to czy zakończyli już działania wolontariackie, czy je kontynuują, to wypowiadają się o swoich doświadczeniach w aktywności wolontariackiej pozytywnie oraz zauważają wiele korzystnych zmian w swoim życiu wynikających z podejmowanych działań. Zmiany negatywne, które akcentują, głównie dotyczą problemów natury fizycznej, zdrowotnej związanej z wysiłkiem. Jednak najwięcej i najdłużej moi rozmówcy mówią o zmianach pozytywnych.

Na podstawie przeprowadzonych przeze mnie badań wygenerowałam następujące kategorie motywów, którymi kierowały się badane osoby.

Pierwszą kategorią motywów jest zmiana wizerunku/ percepcji siebie (korzyści osobiste, zmiana w postrzeganiu niepełnosprawności). Do nich można zaliczyć takie cechy wymienione przez respondentów, jak: odpowiedzialność za swoje postępowanie, otwartość na ludzi, asertywność, poprawa samooceny, zahartowanie charakteru, zwiększenie wrażliwości, odwaga, poczucie satysfakcji z faktu udzielenia innym pomocy. Respondenci nabrali przekonania, że mimo wózka czy innych ograniczeń można zrobić wiele rzeczy i że te ograniczenia nie są przeszkodą, by dać sobie radę w różnych życiowych sytuacjach i nie czuć się jak persona non grata. Wolontariat utwierdził ich w przekonaniu, że potrafią sprostać nawet trudnym wyzwaniom. Nauczyli się pozytywnego myślenia o swojej niepełnosprawności, znajdywania mocnych punktów w sobie. Ponadto zauważyli u siebie większą wrażliwość na problemy innych osób, a nie tylko na skupieniu się na własnej niepełnosprawności.

Druga kategoria motywów odnosi się do zmiany rzeczywistości (umiejętności i kompetencje, umiejętność organizacji, poznanie środowiska pracy). Respondenci podkreślali nabycie nowych umiejętności, w tym interpersonalnych, radzenia sobie ze stresem, umiejętności w rozwiązywaniu konfliktów i wypracowywaniu kompromisów, nauczeniu się różnych czynności zawodowych przy braku stresu związanego z obawą utraty pracy. Doświadczenia wolontariackie pomogły im w poszerzeniu horyzontów myślowych, nauczenia się pracy w grupie. Ponadto wolontariat był często inspiracją w wyborze drogi kariery zawodowej. Respondenci podkreślali, że nauczyli się ustalania priorytetów, organizacji czasu pracy, a także czasu wolnego.

Trzecia kategoria to motywy jako punkt zwrotny w życiu. Często respondenci akcentowali, że wolontariat był punktem zwrotnym w ich życiu. Stali się pewni siebie, samodzielni, przestali liczyć na parasol ochronny rodziny. Podkreślali pozytywne aspekty integracji z osobami sprawnymi, zwłaszcza akceptacji ich osoby.

AS: Najszczęśliwszy dzień w życiu, to akceptacja mojej osoby.

Ważne również okazało się poczucie więzi, przynależności do grupy i poznanie innych osób.

Podsumowując dotychczasowe rozważania, można skonstatować, że praca w wolontariacie, rzetelne wykonywanie nałożonych obowiązków może stać się podstawą do budowania własnej tożsamości, sprawdzania się w różnych rolach i sytuacjach życiowych, zainteresowania się ambitniejszymi kwestiami życia niż własny wygląd czy urojona odwaga. Wolontariat stwarza możliwości podołania wielu wyzwaniom, co konstytuuje wiarę we własne siły. Poza tym tego rodzaju zaangażowanie pozwala na odkrycie radości z dzielenia się tym, czym człowiek sam dysponuje (Segiet 2005: 123). 
Potrzeba działania jest nierozerwalnie związana z życiem człowieka, jego aktywnością w różnych formach uczestnictwa społecznego. Największe możliwości działania tkwią w samej osobie niepełnosprawnej, w jej postawie życiowej, w akceptacji swojej niepełnej sprawności. Bardzo ważne są umiejętności społeczne osób niepełnosprawnych, w tym właściwego interpretowania zachowań innych ludzi.

Osoby niepełnosprawne podejmują działania społeczne w różnych formach, najczęściej są to działania oparte na wolontariacie. W strukturach formalnych i nieformalnych działających na rzecz osób niepełnosprawnych funkcjonują osoby sprawne i niepełnosprawne, aktywne i będące tylko odbiorcami podejmowanych w ramach zadań statutowych przedsięwzięć. Ważne w funkcjonowaniu takich struktur są relacje między członkami, ich aktywność, zwłaszcza zorientowana na zmianę otaczającej rzeczywistości. Wydaje się, że duża liczba organizacji działających w trzecim sektorze i nie tylko nie odkryła jeszcze potencjału niepełnosprawnych wolontariuszy. Może to wynikać z dość upowszechnionego stereotypu, zgodnie z którym osoby niepełnosprawne to przede wszystkim odbiorcy działań. Podstawowa obawa, jaka wiąże się z zaangażowaniem osób niepełnosprawnych, to ich stan zdrowia, słabsza kondycja fizyczna i niesamodzielność. Niepokój może budzić także konieczność poświęcenia więcej czasu na wprowadzenie w sprawy merytoryczne czy sposób działania danej organizacji.

Wolontariat jest dla moich rozmówców celem samym w sobie, a także środkiem do podjęcia innej aktywności, czy to społecznej, czy to zawodowej. Z moich badań wynika, że działalność wolontariacka osób niepełnosprawnych jest pożądaną drogą wyjścia z bierności i wykluczenia. Wzmacnia poczucie ich wartości, sprawia, że stają się bardziej chętni do podjęcia innych aktywności, czują w sobie siły do pokonywania barier. Osoby niepełnosprawne odnajdują sens życia w pomaganiu innym.

Niepełnosprawność traktowana jako normalność powinna przyczynić się do powstania naturalnych relacji między ludźmi sprawnymi i niepełnosprawnymi.

\section{BIBLIOGRAFIA}

Ardeńska, Agnieszka i Rajmund Tomik. 2014. Motywacja wewnętrzna, zewnętrzna i amotywacja na studiach w obszarze kultury fizycznej, „Rozprawy Naukowe AWF we Wrocławiu", 47: 70-79.

Barnes, Colin i Geoffrey Mercer. 2008. Niepetnosprawność, Warszawa: Wydawnictwo „Sic!”. Blumer, Herbert. 2007. Interakcjonizm symboliczny: perspektywa i metoda, Kraków: Zakład Wydawniczy „NOMOS”.

Dziewulski, Henryk. 1984. Alfred Schutz - uspołecznienie pojmowania świata, „Studia Socjologiczne", 3 .

Fabisiak, Joanna (red.). 2002. Młodzieżowy wolontariat, Warszawa: Fundacja Świat na Tak. Gliński, Piotr i Hanna Palska. 1997. Cztery wymiary społecznej aktywności obywatelskiej, w: Henryk Domański i Andrzej Rychard (red.), Elementy nowego ładu, Warszawa: Wydawnictwo IFiS PAN.

Gąciarz, Barbara. 2014. Integracja społeczna i aktywizacja zawodowa osób niepetnosprawnych zamieszkałych $w$ matych miastach i na terenach wiejskich: uwarunkowania sukcesów i niepowodzeń: raport z badań, Warszawa: Wydawnictwo IFiS PAN. 
Giermanowska, Ewa, Agnieszka Kumaniecka-Wiśniewska, Mariola Racław i Elżbieta Zakrzewska-Manterys. 2015. Niedokończona emancypacja Wejście niepetnosprawnych absolwentów szkót wyższych na rynek pracy, Warszawa: Wydawnictwo Uniwersytetu Warszawskiego.

Goffman, Erving. 1963/2005. Piętno. Rozważania o zranionej tożsamości, Gdańsk: Gdańskie Wydawnictwo Psychologiczne.

Górecki, Mirosław. 1999. Wolontariat, w: Danuta Lalak i Tadeusz Pilch (red.), Elementarne pojęcia pedagogiki społecznej i pracy socjalnej, Warszawa: Wydawnictwo Akademickie Żak.

Grotowska-Leder, Jolanta. 2008. Sieci wsparcia społecznego jako przejaw integracji $i$ dezintegracji społecznej, Łódź: Wydawnictwo Uniwersytetu Łódzkiego.

Kanios, Anna. 2010. Społeczne kompetencje studentów do pracy w wolontariacie, Lublin: Wydawnictwo UMCS.

Maslow, Abraham H. 1990. Motywacja i osobowość, Warszawa: Instytut Wydawniczy Pax.

Michalik M. 1998. Aksjologiczne uwarunkowania aktywności społecznej, w: Ryszard Sztychmiler (red.), Aktywność społeczna. Warunki prawne i formy aktywności w społeczności świeckiej i kościelnej. Materiaty z konferencji naukowej, Olsztyn 21-22 maja 1996 roku, Wydawnictwo Wyższej Szkoły Pedagogicznej.

Mikołajczyk-Lerman, Grażyna. 2013. Między wykluczeniem a integracją: realizacja praw dziecka niepetnosprawnego i jego rodziny: analiza socjologiczna, Łódź: Wydawnictwo Uniwersytetu Łódzkiego.

Misztal, Jan. 2007. Człowiek w organizacji, Gliwice: Wydawnictwo Politechniki Śląskiej.

Marody, Mirosława i inni. 2019. Społeczeństwo na zakręcie. Zmiany postaw i wartości Polaków w latach 1990-2018, Warszawa: Wydawnictwo Naukowe Scholar.

Moroń, Dorota. 2009. Wolontariat w trzecim sektorze. Prawo i praktyka, Wrocław: Wydawnictwo Uniwersytetu Wrocławskiego.

Ostrowska, Antonina i Joanna Sikorska. 1997. Syndrom niepetnosprawności w Polsce: bariery integracji, Warszawa: Wydawnictwo IFiS PAN.

Penc, Józef. 2000. Motywowanie w zarzadzaniu, Kraków: Wydawnictwo Profesjonalnej Szkoły Biznesu.

Ryan, Richard M. i Edward L .Deci. 2000. Self-determination theory and the facilitation of intrinsic motivation, social development and well-being, „American Psychologist”, 55: $68-78$.

Ryan, Richard M., Richard Koestner i Edward L. Deci. 1991. Varied forms of persistence: When free choice behaviour is not intrinsically motivated, „Motivation and Emotion”, $15,185-205$.

Rymsza, Marek. 2013. Aktywizacja w polityce społecznej. W stronę rekonstrukcji europejskich welfarestates?, Warszawa: Wydawnictwo IFiS PAN.

Rymsza, Marek. 2016. Niepetnosprawny jako aktywny obywatel - problematyka integracji społecznej $i$ zawodowej osób niepetnosprawnych w Polsce, w: Elżbieta Zakrzewska-Manterys i Jakub Niedbalski (red.), Samodzielni zaradni niezależni. Ludzie niepetnosprawni w systemie polityki pracy i edukacji, Łódź: Wydawnictwo Uniwersytetu Łódzkiego, s. 13-46.

Słownik języka polskiego. 2015. Warszawa: Wydawnictwo Naukowe PWN. 
Segiet, Katarzyna. 2005. Znaczenie wolontariatu działajacego na rzecz dzieci i młodzieży w różnych obszarach życia społecznego, w: Barbara Kromolicka (red.), Wolontariat w obszarze humanistycznych wyzwań opiekuńczych, Toruń: Wydawnictwo Edukacyjne „Akapit”.

Sekuła, Zofia. 2008. Motywowanie do pracy. Teorie i instrumenty, Warszawa: Polskie Wydawnictwo Ekonomiczne.

Śpiewak, Paweł. 2018. Klasyczne teorie socjologiczne: wybór tekstów, Warszawa: Wydawnictwo Naukowe PWN.

Turner, Jonathan H. 1998. Socjologia: podstawowe pojęcia i ich zastosowanie, Poznań: Wydawnictwo Zysk i S-ka.

Wiszejko-Wierzbicka, Dorota. 2010. Niewykorzystana sfera: partycypacja społeczna i obywatelska osób z ograniczeniami sprawności, Warszawa: Wydawnictwo Naukowe Scholar.

Woźniak, Zbigniew. 2008. Niepetnosprawność i niepelnosprawni w polityce spolecznej. Społeczny kontekst medycznego problemu, Warszawa: Wydawnictwo Naukowe Szkoły Wyższej Psychologii Społecznej Academica, s. 78-79.

Żuraw, Hanna. 2008. Udział osób niepetnosprawnych $w$ życiu społecznym, Wydawnictwo Akademickie Żak, 9.

Ustawa z dnia 24 kwietnia 2003 r. o działalności pożytku publicznego i o wolontariacie. Dz.U. z 2003 r., nr 96, poz. 873.

Ustawa z dnia 7 kwietnia 1989 r. Prawo o stowarzyszeniach, Dz.U. z 1989 r., nr 20, poz. 104.

\section{DISABLED VOLUNTEER - OF THEIR OWN NEEDS OR OF THINKING OF OTHERS}

"The most immutable and significant question of life is: What do you do for others?" (Martin Luther King Jr). This is the essence of volunteering, which involves conscious and selfless work for the community, it is showing help, but also a lesson in asking for it. The answer to this question is not easy, especially for a disabled person. The purpose of the article is to try to answer the question whether a disabled person can also be a donor of voluntary activities, and not just their recipient. Social participation, related volunteers is an attempt to answer the questions: what factors, procedures or mechanisms are behind undertaking social activity or lack of it, whether volunteering activity of disabled people is a desirable way out of the circle of excluded people.

Keywords: activation, social activity, physical disability, disabled volunteers, volunteer activities

Zgłoszenie artykułu: 20.03.2020

Recenzje: 21.04 .2020

Rewizja: 7.05.2020

Akceptacja: 8.05.2020

Publikacja on-line: 30.09 .2020 